\title{
“Ayurveda for Covid 19" Survey Analysis
}

Dr. Aakash Kembhavi MD*, Dr. Anita Kadagad Kembhavi

Director, Astanga Wellness Pvt Ltd, flat G1, 1st Floor, Mahima Dahalia Apartments, Near New Court Complex, Timmasagar Colony, Vidyanagar, Hubli - 580021. Karnataka, India

DOI: $10.36348 /$ sijtcm.2020.v03i05.001

| Received: 22.04.2020 | Accepted: 05.05.2020 | Published: 13.05 .2020

*Corresponding author: Dr. Aakash Kembhavi

\section{Abstract}

Since the WHO announced Covid 19 as a global pandemic, the government of India started adopting strategies to tackle the crisis and ramp up the health infrastructure to deal with the cases. In this backdrop it was watched with great expectation that Ayurveda, the traditional health care system of India would be considered to play a role in the management of cases. During this period there were a lot of discussions on social media groups by Ayurveda physicians across the country questioning as to why Ayurveda was still not being considered? This provided the stimulus to develop the survey "Ayurveda for Covid 19" and was released on the $29^{\text {th }}$ of March 2020 by the authors to collect opinions and suggestions on the issue. A total of 17 questions were created with multiple choice options and a few questions were open ended for respondents to suggest single herbs, herbal and herbo-mineral formulations that could be used in the management of Covid 19 cases. A total of 449 responses were received by the authors and these were analyzed and a report was generated. This report was then used by the authors to develop a proposal titled "Comprehensive Ayurveda Treatment Response Strategy for Covid 19" on the 2 nd of April 2020 which was submitted to the Government of India. The authors present the analysis and its implications.

Keywords: Ayurveda Covid 19, global pandemic.

Copyright @ 2020: This is an open-access article distributed under the terms of the Creative Commons Attribution license which permits unrestricted use, distribution, and reproduction in any medium for non-commercial use (NonCommercial, or CC-BY-NC) provided the original author and source are credited.

\section{INTRODUCTION}

Since the WHO announced Covid 19 as a global pandemic [1], the government of India started adopting strategies to tackle the crisis and ramp up the health infrastructure to deal with the cases. In this backdrop it was watched with great expectation that Ayurveda, the traditional health care system of India would be considered to play a role in the management of cases, since there were reports that Traditional Chinese Medicine was adopted in China to deal with their patients [2]. But there were no announcements forthcoming and the Ministry of Ayush too had not given out any statements at least in terms of setting up an Ayurveda Task Force to study the prospects of Ayurveda being used and to develop a protocol that could be implemented nation- wide.

During this period there were a lot of discussions on social media groups by Ayurveda physicians across the country questioning as to why Ayurveda was still not being considered? This provided the stimulus to develop the survey 'Ayurveda for Covid 19" [3] and was released on the $29^{\text {th }}$ of March 2020 by the authors to collect opinions and suggestions on the issue. A total of 17 questions were created with multiple choice options and a few questions were open ended for respondents to suggest single herbs, herbal and herbo-mineral formulations that could be used in the management of Covid 19 cases.

The prime minister of India interacted with Ayurveda physicians and other stake holders which were successful to an extent that the prime minister appealed to the Ayurveda fraternity to come up with robust scientific evidence [4]. It later was announced that certain principles of Ayurveda can be adopted by the general public to develop their immunity which is now being widely advised across all media. The states of Kerala [5] and Goa [6] have become the first amongst the states to approve Ayurveda approaches in the clinical management of Covid 19 positive cases along with modern medical treatments.

A total of 449 responses were received by the authors and these were analyzed and a report was generated. This report was then used by the authors to develop a proposal titled "Comprehensive Ayurveda Treatment Response Strategy for Covid 19" on the $2^{\text {nd }}$ of April 2020 which was submitted to the Government of India. 
The details of the Survey

\begin{tabular}{|l|l|l|}
\hline S.No & Particulars & Details \\
\hline 1 & Basic Premise of the Survey & $\begin{array}{l}\text { To collect opinions of Ayurveda doctors on the possibility of the } \\
\text { role of Ayurveda in the management of Covid 19 cases. }\end{array}$ \\
\hline 2 & Date of release of the survey & $29^{\text {th }}$ March 2020 \\
\hline 3 & Tool used for Survey & Google Forms \\
\hline 4 & Total Number of Questions in the Survey & 17 \\
\hline 5 & Total responses received & 449 \\
\hline
\end{tabular}

\begin{tabular}{|l|l|c|}
\hline Categories of Questions \\
\hline Particular & Area & Number of Questions \\
\hline Section 1 & Ayurveda for Covid 19 & 08 \\
\hline Section 2 & Ayurveda Task Force related & 02 \\
\hline Section 3 & Demographic & 04 \\
\hline Section 4 & Medicines recommendations & 03 \\
\hline & Total Number of questions & $\mathbf{1 7}$ \\
\hline
\end{tabular}

The survey provided insightful inputs from the respondents and the charts presented below are taken from the Google Forms Analytical content and are self explanatory. The discussion and conclusion will follow after these charts.

\section{Section1: Ayurveda for Covid 19 questions}

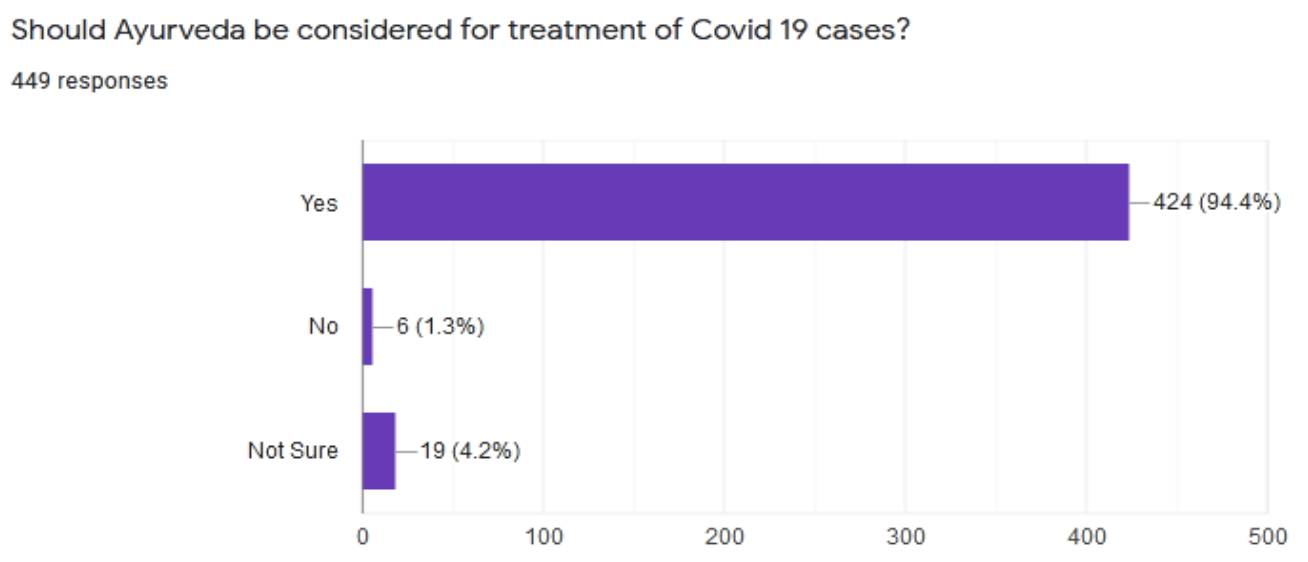

An overwhelming 94.4\% of respondents said that Ayurveda should be considered for treatment of Covid 19 cases.

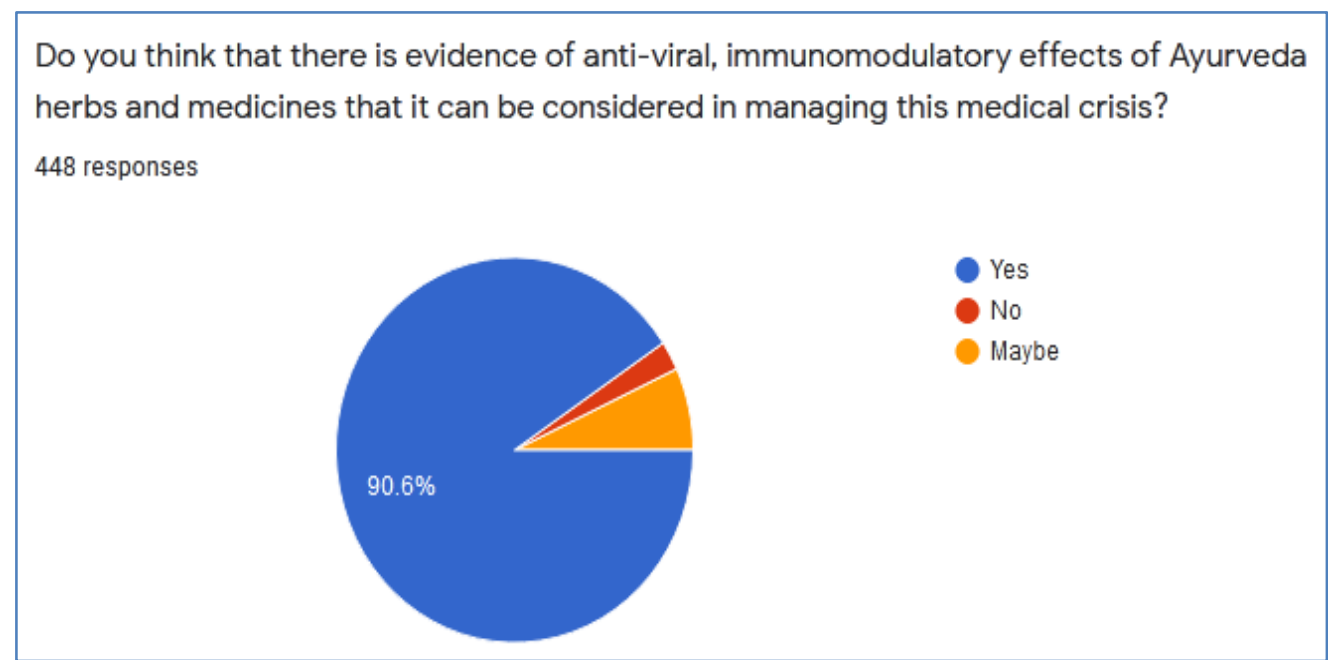

$90 \%$ of respondents believed there is evidence of Ayurveda herbs and medicines that possess anti-viral and immunomodulatory effects. 
Can Ayurveda medicines prevent a person from developing the infection?

449 responses

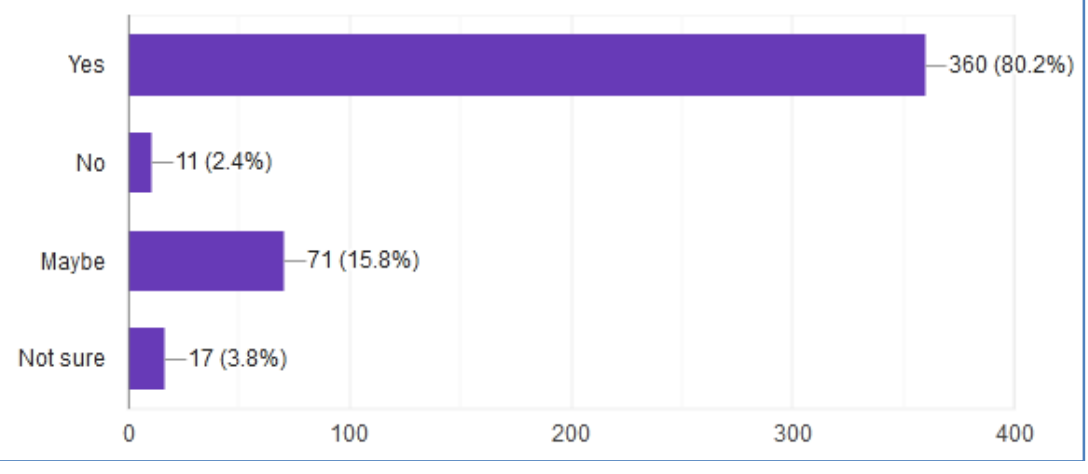

At what stage of Covid 19 can Ayurveda treatment be implemented? (You can tick as many boxes as applicable)

449 responses
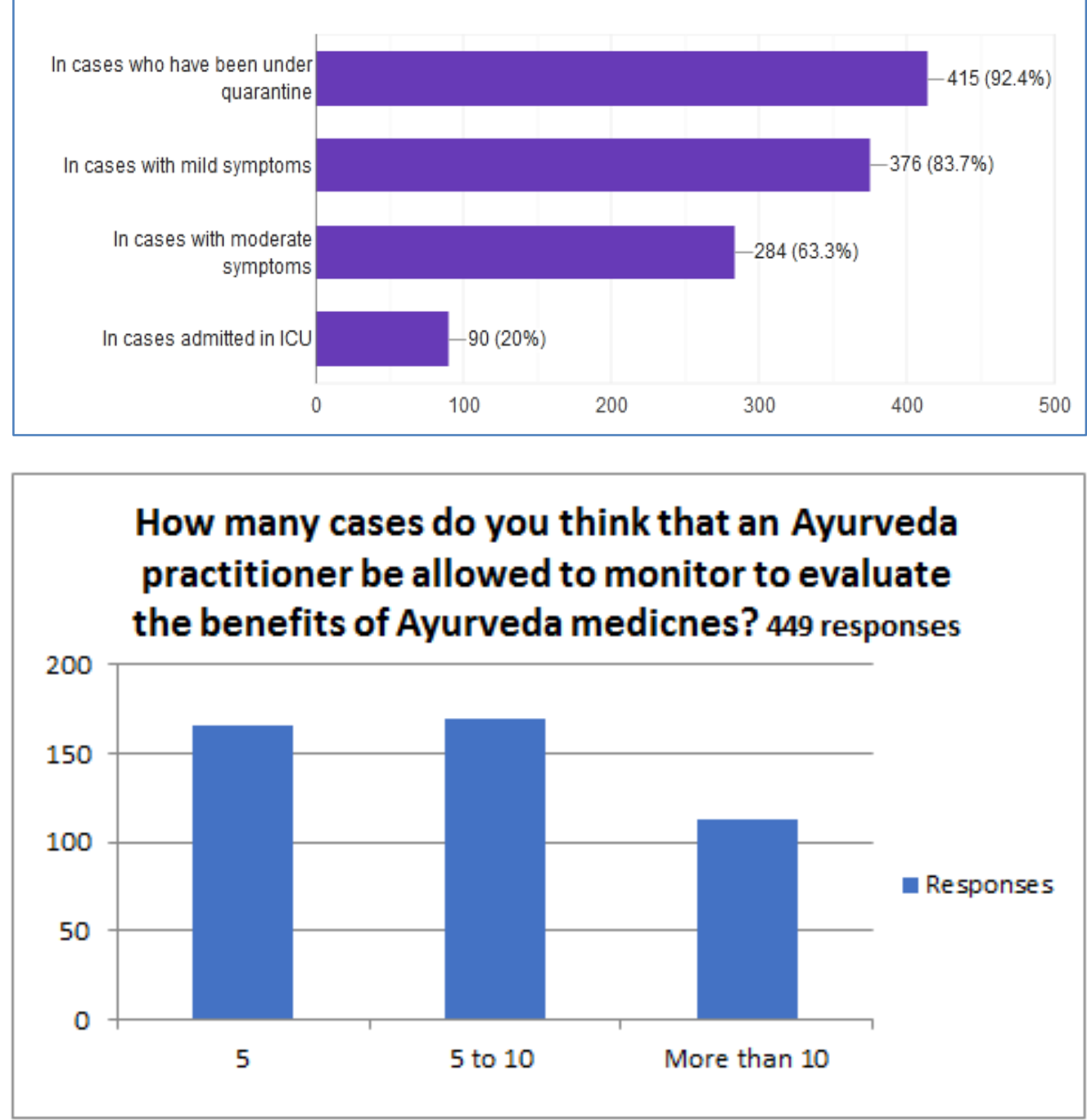
Should Ayurveda Medicines be advised to the general public to improve their immunity? 449 responses
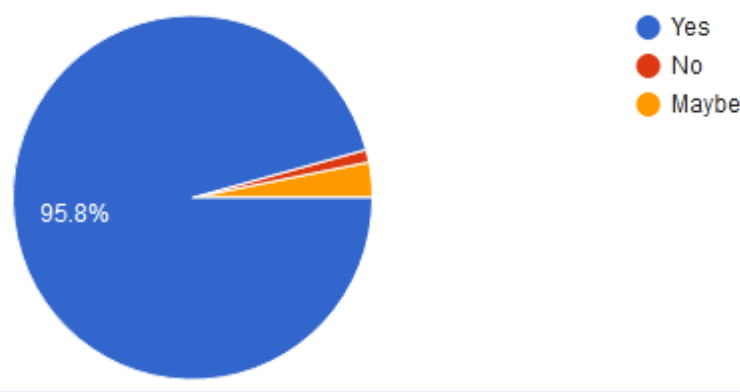

Which of the following do you think should be advised to the general population to be followed on a daily basis? (You can tick as many boxes as applicable)

449 responses

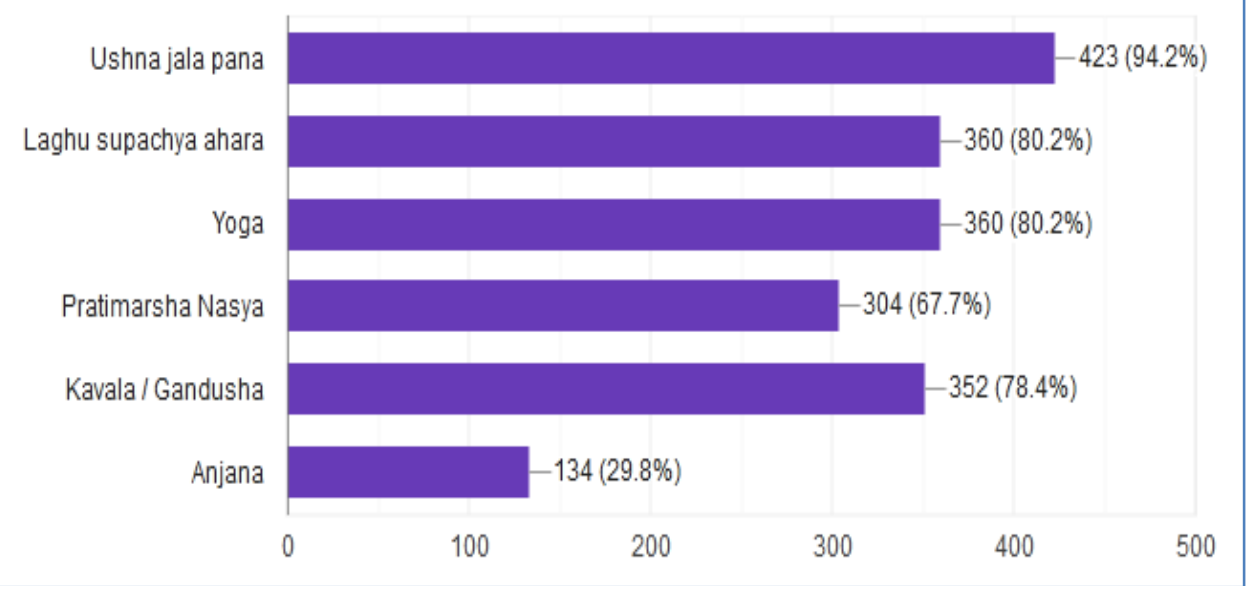

Section 2: Ayurveda Task Force related questions

Should an Ayurveda Task Force be set up to tackle the Covid 19 crisis?

449 responses

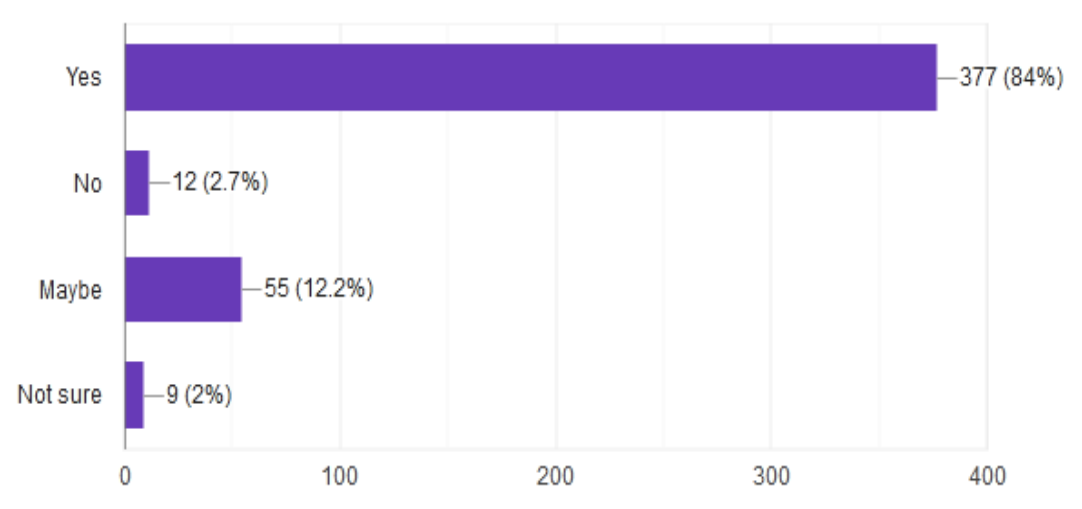




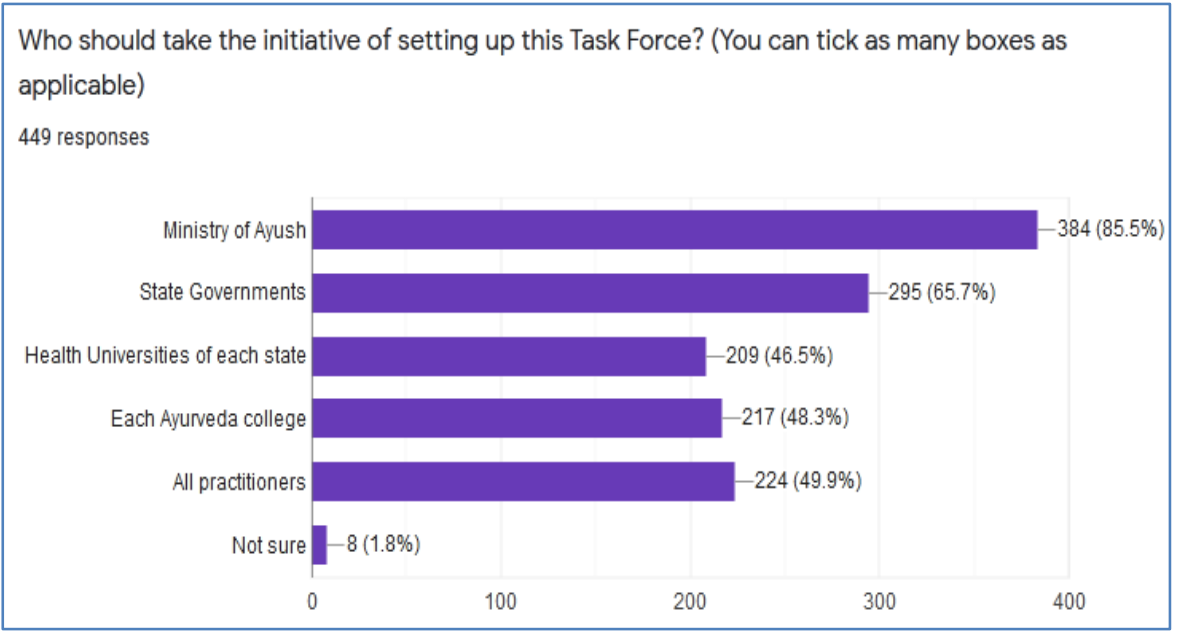

\section{Section 3: Demographic data:}

\section{Gender}

449 responses
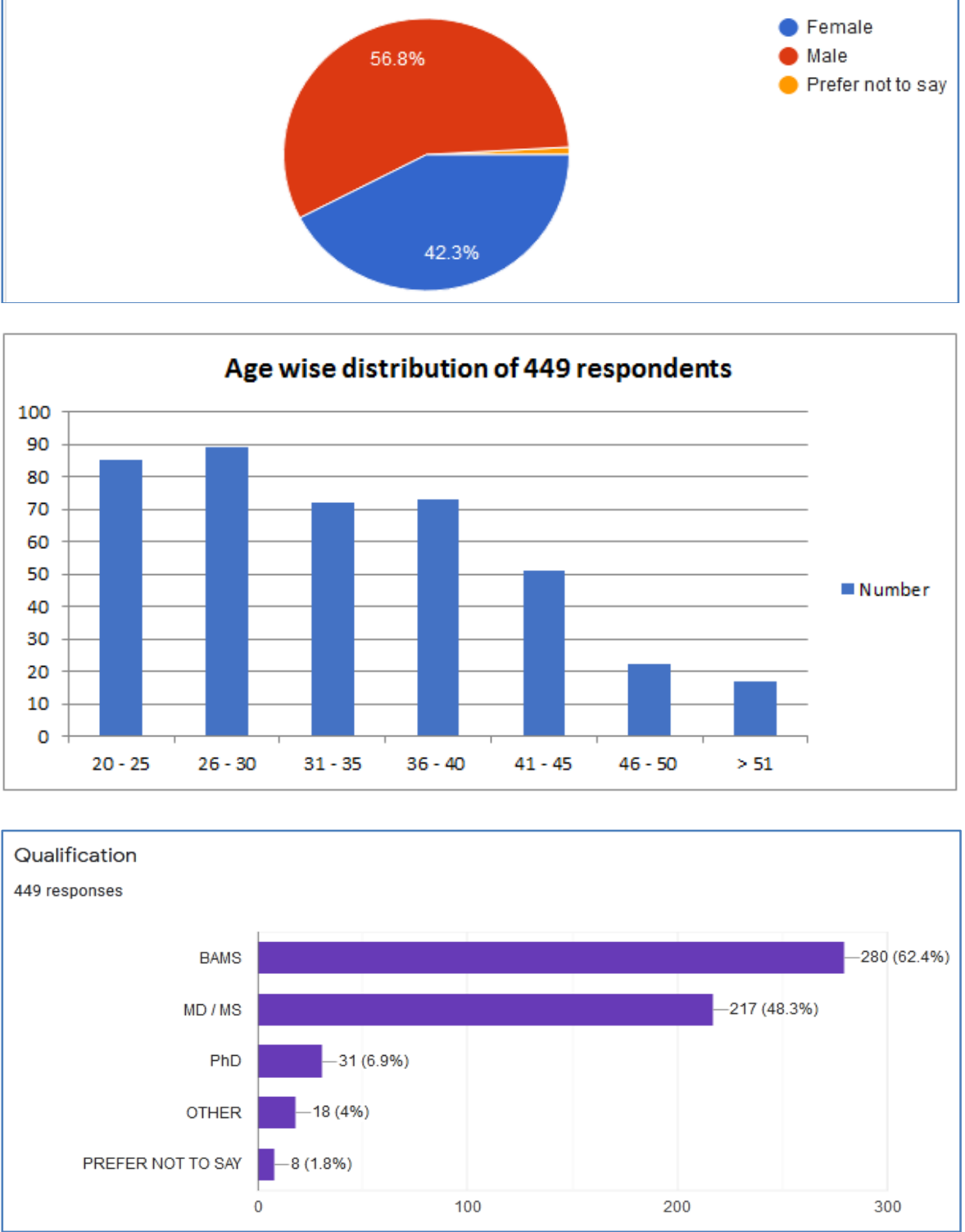
Aakash Kembhavi \& Anita Kadagad Kembhavi., Sch Int J Tradit Complement Med, May, 2020; 3(5): 81-89

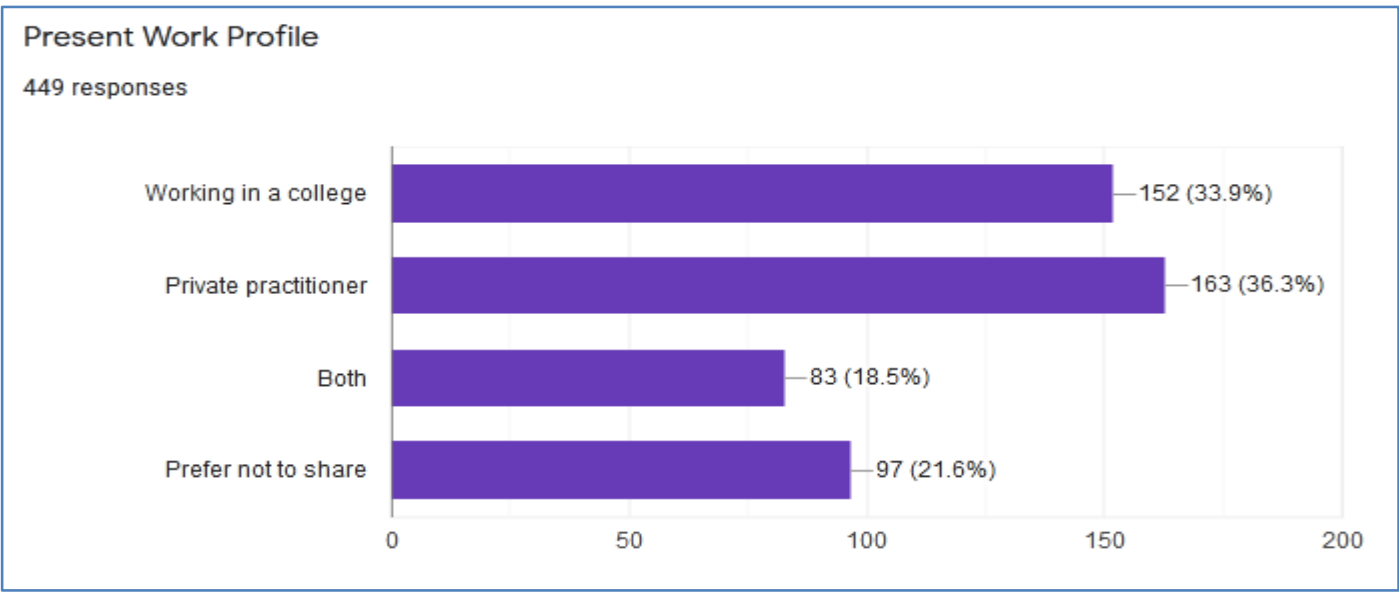

\section{Section 4: Medicines related}

Single Herb Recommendations for the treatment of Covid 19 cases by the respondents:

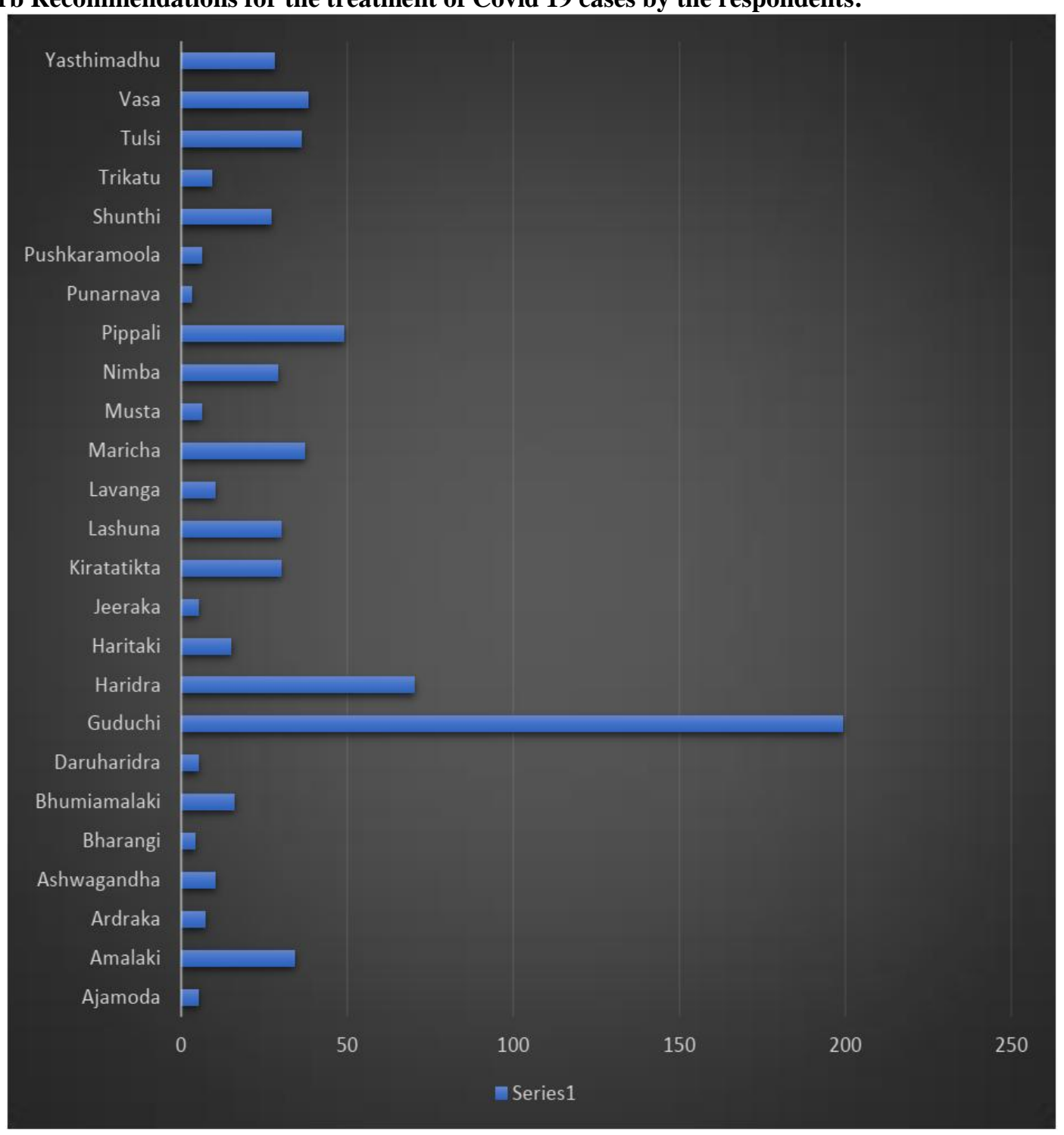




\section{Herbal Formulations recommended by the repsondents for the treatment of Covid 19 cases:}

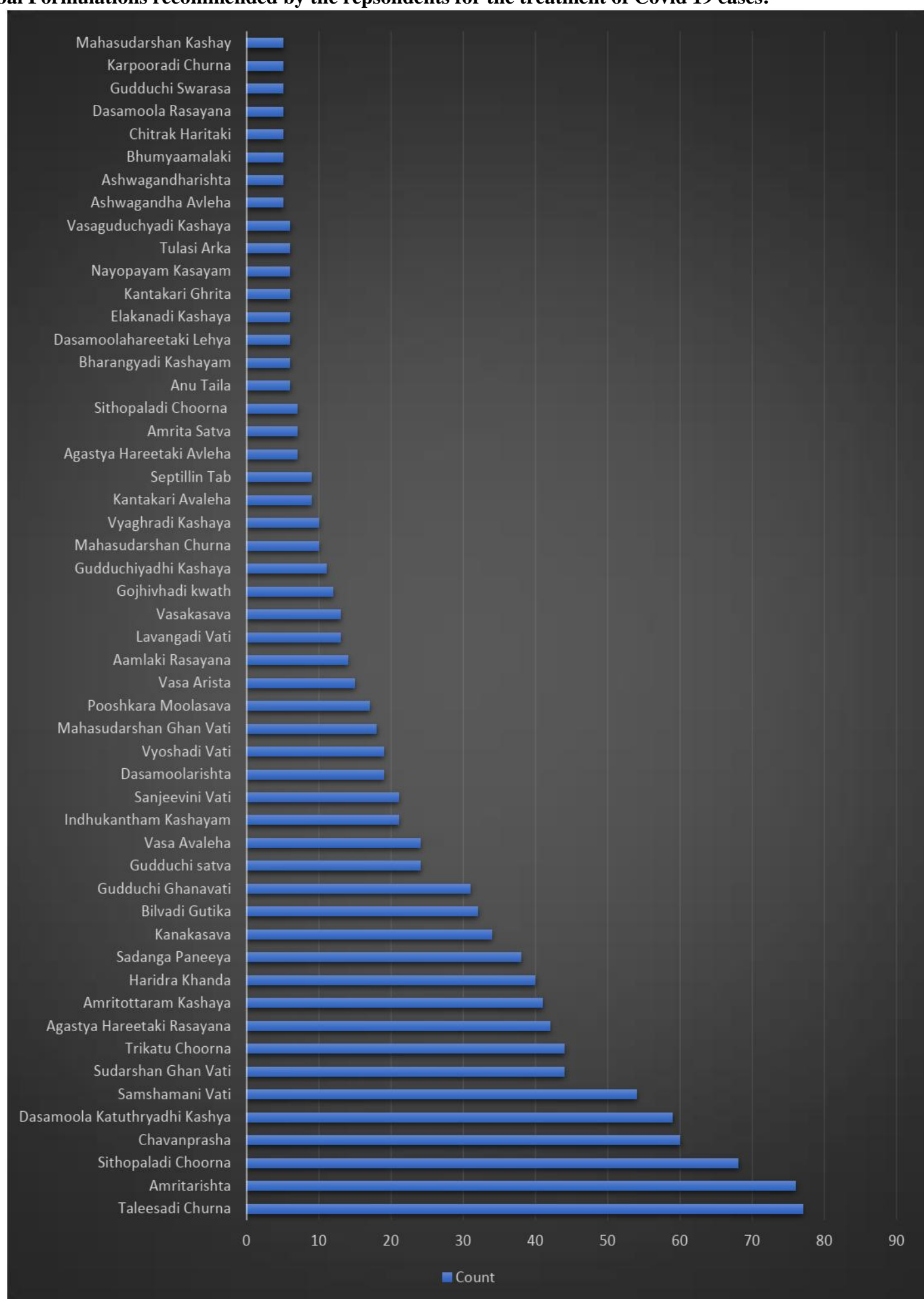




\section{Rasaushadhies recommended by the respondents for the treatment of Covid 19 cases:}

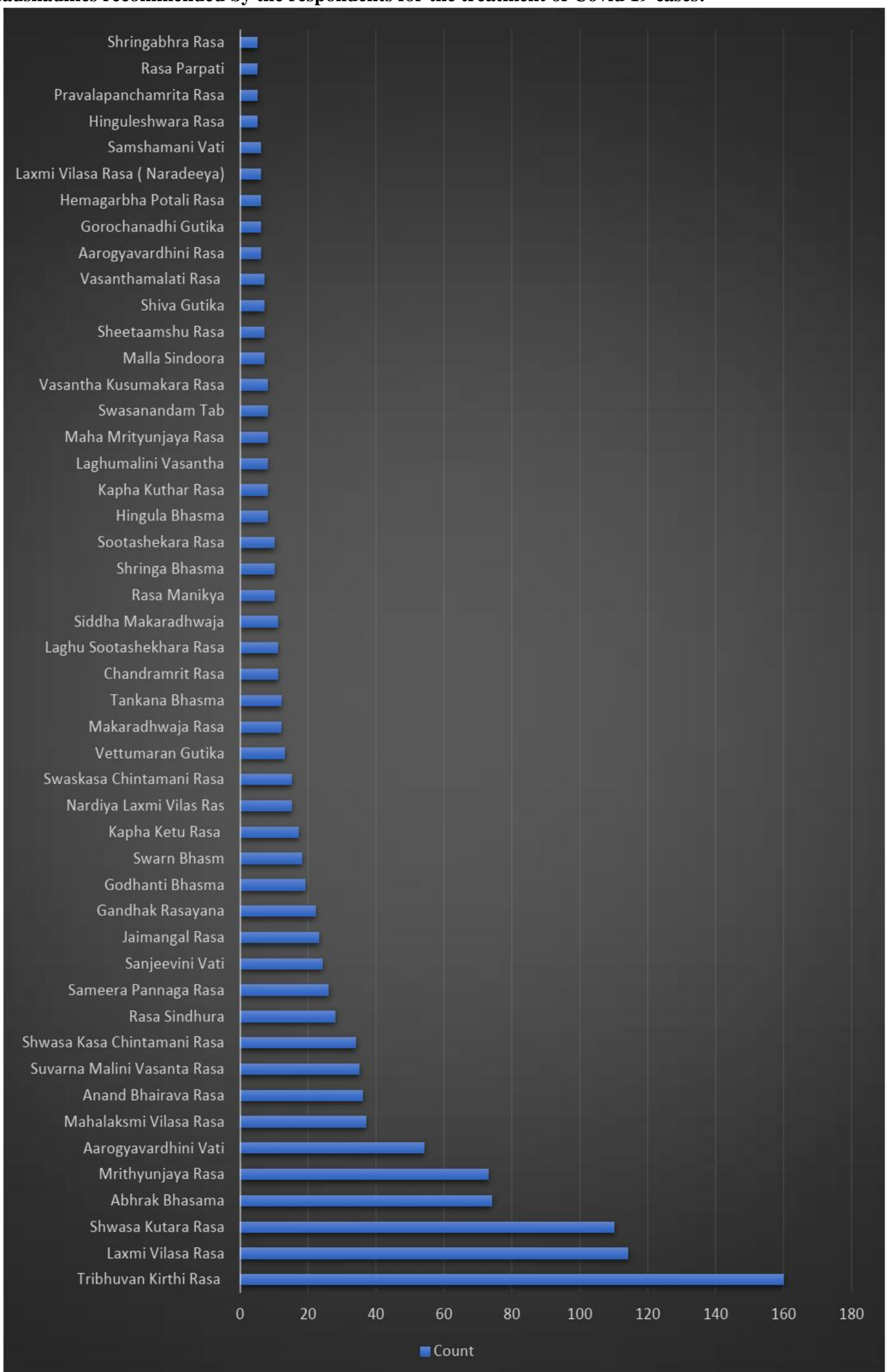




\section{DISCUSSION}

\section{Section 1: Ayurveda for Covid 19}

It is clearly evident from the responses received that a vast majority of Ayurveda practitioners opine that Ayurveda definitely has a role to play in the management of Covid 19 cases. There is sufficient scientific research evidence that Ayurveda herbs and formulations possess anti- viral and immunomodulatory actions and can be utilised in the management of Covid 19 positive cases. A pilot study of 5 to 10 Covid 19 positive cases in quarantined conditions and those with mild to moderate symptoms should be studied to establish the efficacy of Ayurveda medicines and to develop a protocol which can then be implemented across the country.

\section{Section 2: Ayurveda Task Force related}

There is an unanimous voice that an Ayurveda Task Force to tackle the clinical challenges of Covid 19 cases should be set up and it is the responsibility of the Ministry of Ayush to do so.

\section{Section3; Demographic data}

Both male and female respondents registered their responses and a majority of them were in the age group of 20 to 45 years. A majority of the responders were post graduate degree holders and all were practising Ayurveda doctors privately or either attached to a college.

\section{Section 4: Medicines related}

Single herbs recommendations: Guduchi, Haridra, Yastimadhu, Vasa, Amalaki, Tulsi, Kiratatikta, Lashuna, Pippali, Shunthi and Maricha were the most recommended single herbs for the management of Covid 19 cases.

Herbal formulations recommendations: Mahasudrashan Ghana vati, Dashamoolarista, Amritarista, Taleesadi and Sitopaladi churna, Haridra khanda, Agastya rasayana, Guduchi satwa, Shadanga paneeya, Samshamani vati, Chyavanaprasha, Amrutottaram kashaya, Dashamoolakatutrayadi kashayam etc were recommended by the respondents.

\section{Rasaushadhies}

recommended:

Tribhuvanakeerti rasa, Abhraka bhasma, Shwasa kuthara rasa, Laxmivilasa rasa, Arogyavardhini rasa, Mrityunjaya rasa, Shwasakasa chintamani rasa, Suvarnamalini vasanta rasa, Gandhaka rasayana, Jayamangala rasa, Godanti bhasma etc were the recommendations collected from the survey.
From the above list of recommended herbs and formulations it can be understood that the participants of teh survey have thought about Jwara, Shwasa, Rajayakshma and related diseases to manage covid 19 cases.

\section{CONCLUSION}

The survey was created to collect the opinion of Ayurveda practitioners across India with relation to the possibility of developing a management protocol for Covid 19 cases in our country.

It is very clear that an Ayurveda Task Force must be set up to develop the protocol. The survey responses were utilised by the authors to develop a proposal tilted, "A Comprehensive Ayurveda Treatment Response Strategy for Covid 19" which has been submitted to the Ministry of Ayush and the PM and PMO of India.

The ministry of Ayush on $23^{\text {rd }}$ April 2020, has announced that it will expedite the EMR research proposals from Ayurveda institutions in the management of Covid 19 cases.

\section{REFERENCES}

1. https://www.who.int/dg/speeches/detail/whodirector-general-s-opening-remarks-at-the-mediabriefing-on-covid-19---11-march-2020

2. https://news.cgtn.com/news/2020-04-16/Beijingapproves-TCM-drugs-for-COVID-19-

PJWgGfRAQg/index.html

3. https://docs.google.com/forms/d/e/1FAIpQLSeEu4 new_Z3x9dEMeS7HJjnARhr6IE7eLlcVoGLAg2nX$\mathrm{gzA} /$ viewform?usp=sf_link

4. https://www.google.com/url?sa=t\&source=web\&rc $\mathrm{t}=\mathrm{j} \&$ url=https://indianexpress.com/article/coronavir us/ayush-task-force-on-covid-19-looks-atpromising-ayurvedic-medicines-for-clinical-drugtrials-

6362755/lite/\&ved=2ahUKEwiEts735fToAhUGey sKHV0FDcoQFjAGegQIAhAB\&usg=AOvVaw16 VxOW12dg-CJb77tGV08U\&ampcf=1

5. https://www.google.com/amp/s/medicaldialogues.i n/amp/state-news/kerala/kerala-plans-on-usingayurveda-to-mitigate-covid-19-spread-64755

6. https://www.google.com/amp/s/www.deccanherald .com/amp/national/west/goa-to-use-ayurveda-toboost-immunity-of-patients-of-coronavirus823368.html. 